\title{
A unique zinc finger protein is associated preferentially with active ecdysone-responsive loci in Drosophila
}

\author{
Sally A. Amero, ${ }^{1}$ Sarah C.R. Elgin, ${ }^{2}$ and Ann L. Beyer ${ }^{1}$ \\ ${ }^{1}$ Department of Microbiology, University of Virginia School of Medicine, Charlottesville, Virginia 22908 USA; ${ }^{2}$ Department \\ of Biology, Washington University, St. Louis, Missouri 63130 USA
}

\begin{abstract}
Using an immunochemical approach, we have identified a unique antigen, PEP (protein on ecdysone puffs), which is associated in third-instar larvae with the active ecdysone-regulated loci on polytene chromosomes; PEP is not associated with most intermolt puffs and is found on some, but not all, heat shock-induced puffs. The distribution pattern changes with changing puffing patterns in the developmental program. We have screened an expression library and recovered a cDNA clone encoding PEP. PEP possesses multiple potential nucleic acid- and protein- binding regions: a glycine- and asparagine-rich amino terminus, four zinc finger motifs, two very acidic segments, two short basic stretches, and an alanine- and proline-rich carboxyl terminus. The Pep gene maps by in situ hybridization to the cytological locus $74 \mathrm{~F}$, adjacent to the early ecdysone-responsive region; however, the gene is not regulated by ecdysone at the level of transcription. The pattern of Pep expression through development suggests that maternal Pep gene transcripts are supplied to the embryo, and that the abundance of Pep gene transcripts decreases to a lower, fairly constant level thereafter. This unusual protein may play a role in the process of gene activation, or possibly in RNA processing, for a defined set of developmentally regulated loci.
\end{abstract}

[Key Words: Drosophila; ecdysone puffs; locus 74F; polytene chromosomes; zinc fingers]

Received October 3, 1990; revised version accepted November 19, 1990.

The giant polytene chromosomes of Drosophila melanogaster provide a unique opportunity to assay the protein interactions at defined genetic loci, because specific proteins can be localized on the chromosomes through indirect immunochemical assays (e.g., Elgin et al. 1988). Analyses of this type have provided a general picture of transcriptional activity in puffs and interbands from the distribution patterns of RNA polymerase II (Sass 1982; Weeks et al. 1982) and topoisomerase I (Fleischmann et al. 1984|. The presence of heterogenous nuclear ribonucleoproteins, (hnRNPs) (S.A. Amero and A.L. Beyer, unpubl.) and small nuclear ribonucleoproteins (snRNPs) (Sass and Pederson 1984; S.A. Amero and A.L. Beyer, unpubl.), which are involved in packaging and processing of nascent RNA molecules (Dreyfuss 1986; Zieve and Sauterer 1990), is also observed at these sites.

A coordinated program of developmental gene expression is visible as a reproducible, temporal pattern of puffing activity on the polytene chromosomes (Ashburner 1970). Three sets of chromosomal loci are included in the program, which is initiated in response to ecdysteroid hormones (Hodgetts et al. 1977). The existing intermolt puffs (including loci 25AC, 68C, and 90BC) regress; several "early" puffs (including loci 2B, 22B, 23E, 63F, $74 \mathrm{EF}$, and $75 \mathrm{~B}$ ) appear quickly and then regress. Subsequently, $>100$ "late" puffs appear in a temporal se- quence (Ashburner and Berendes 1978; Pongs 1988). A number of early genes have been cloned (Burtis et al. 1990; Segraves and Hogness 1990; Thummel et al. 1990), and their products may participate in activation of the late genes (Urness and Thummel 1990; for review, see Ashburner 1990|; the products of these late genes are thought to initiate metamorphosis.

A different program of gene expression, and a different puffing pattern, ensues from heat shock or a number of other stresses (Ritossa 1962; Ashburner and Bonner 1979|. Nine puffs, the sites of the genes encoding the heat shock proteins (Spradling et al. 1977), are rapidly induced at $37-38^{\circ} \mathrm{C}$; concomitantly, the developmental puffs regress as transcription at these loci is repressed and splicing of pre-mRNAs is inhibited (Yost and Lindquist 1986). At least one specific factor, the heat shock transcription factor, is required in addition to the basal transcriptional machinery for this induction process (Parker and Topol 1984; Wu 1984).

Using monoclonal antibodies to nuclear proteins from Drosophila embryos, we have identified an unusual protein, PEP (protein on ecdysone puffs), which possesses a distinctive distribution pattern on polytene chromosomes: PEP is associated preferentially with activated, hormone-responsive loci, including both early and late genes but is not found on most intermolt puffs, which 
regress in response to hormone. The pattern of PEP localization reflects the progression of the developmental program. In addition, PEP is associated with some, but not all, heat shock-induced puffs. Cloning of the Pep gene product has revealed the presence of numerous putative nucleic acid-and protein-binding motifs in the unique PEP sequence. In situ hybridization using the cDNA probe places the gene at locus 74F, adjacent to an early ecdysone-responsive region, but Pep gene expression is not regulated at the level of transcription by ecdysone. Thus, PEP is likely to be an important component of selected active loci, recruited in larval stages to complement the transcriptional machinery or splicing apparatus for ecdysone-mediated gene expression.

\section{Results}

PEP is associated preferentially with active, ecdysone-induced puffs

Monoclonal antibodies to nuclear proteins from Drosophila embryos were screened for interesting distribution patterns on polytene chromosomes by indirect immunofluorescence, and mAbs Y1D2 and Y2A11 were chosen for further study. These monoclonal antibodies gave an immunofluorescence distribution pattern covering most visible puffs but few band and interband regions, and no nucleoplasmic or cytoplasmic debris (Fig. 1, B). Remnants of the nucleolus are not stained. mAbs Y1D2 and Y2A11 produce identical staining patterns on the two salivary glands from the same larva (not shown). Subsequent experiments described below show that the two monoclonal antibodies recognize separate epitopes in the PEP antigen.

Fine mapping of the distribution pattern of PEP by the immunofluorescence assay over two larval and two prepupal developmental stages (Table 1) reveals a tight correlation between visible puffing of the developmentally regulated loci and the presence of PEP. Excluding the intermolt puffs, $>90 \%$ of the visible developmental puffs are stained. The few visible puffs that are not stained occur either in the very early or very late stages; the correlation is perfect in the middle stages. Only in several cases is staining detected prior to visible puffing (loci 48B, 52C, and 82F) or following regression (locus 47A). The protein is not associated with the intermolt puffs at loci $25 \mathrm{AC}, 68 \mathrm{C}$, and 90BC in the early puffing stages but is associated with the intermolt puff at locus 3C (not shown). Particularly noteworthy is the intense staining of the ecdysone-responsive puffs at loci 74EF and $75 \mathrm{~B}$ at all stages examined, as these puffs are thought to undergo early activation and late regression in response to ecdysone. Locus $71 \mathrm{DE}$, on the other hand, is puffed throughout these developmental stages but is associated with PEP only in the middle stages. On any given chromosome, the developmental loci listed in Table 1 constitute $\sim 50 \%$ of the total staining pattern for the PEP antigen; the additional sites may represent developmental loci not scored in the original list prepared by Ashburner and Berendes (1978). However, some of these additional sites are consistently stained, such as loci 50CD, 52F, 61E, 70A, and 70D (not shown), and staining at these sites shows no developmental response to ecdysone.

One instructive example of the distribution pattern of PEP is presented in Figure 1, C and D, using mAb Y1D2. Most of the developmental (hormone-responsive) loci that are puffed at stage 2 are stained (loci 22B, 62E, 63F, 69A, 74EF, and 75B/ while the intermolt puff at locus $68 \mathrm{C}$ and the puffs at loci $21 \mathrm{C}, 23 \mathrm{E}$, and 71DE are not. Some of the latter puffs do become stained at later stages, however. Two other developmental loci (63E and 66B) that are induced later in development differ in their staining characteristics on this chromosome; locus 66B is stained rather brightly, while locus $63 \mathrm{E}$ is stained at a much lower level. It is clear by comparison to the distribution pattern of RNA polymerase II on the same chromosome (Fig. 1E) that the sites associated with PEP are a small subset of the loci associated with RNA polymerase and potentially engaged in transcription. In sum, the general features of the distribution pattern of PEP conform to the classical models for a factor involved in expression of the hormone-induced loci. However, the additional sites stained indicate that PEP most likely is involved in other activation systems in addition to that triggered by ecdysone.

The distribution pattern of PEP on chromosomes from heat-shocked larvae also demonstrates a selectivity for certain active loci. Of the nine major heat shock-induced sites, PEP is found at loci $87 \mathrm{~A}, 87 \mathrm{C}, 93 \mathrm{D}$, and $63 \mathrm{BC}$ but not at loci 95D, 64F, and 70A (Fig. 2B,D). Low-level staining is observed at locus 67B (Fig. 2D), and locus 33B was not scored. The heat shock puffs that are associated with PEP do not strictly correspond to those heat shock genes that are also induced by ecdysone, such as the small heat shock protein genes at locus 67B (Zimmerman et al. 1983) or with heat shock genes containing introns, the $h s p 83$ gene at locus 63BC (Yost and Lindquist 1986), and the hsr93D gene at locus 93D (Ryseck et al. 1985; Garbe and Pardue 1986). Thus, PEP is not required for the processes of puffing, transcription, or RNA processing per se. The protein is associated, however, with a particular subset of heat shock-induced loci, as well as a group of developmentally regulated genes and, thus, overlaps two programs of gene expression.

\section{The Pep gene encodes the Y1D2 and Y2A11 epitopes}

Western blots of proteolytic digests of chromosomal proteins showed that $\mathrm{mAbs} Y 1 D 2$ and $\mathrm{Y} 2 \mathrm{~A} 11$ recognize different epitopes in the PEP antigen. A nuclear extract from Drosophila embryos was digested with increasing amounts of trypsin and fractionated by electrophoresis in an SDS-polyacrylamide gel, and the peptides were transferred electrophoretically to a nitrocellulose filter for Western blot analyses. Identical filters were probed with either TBS (not shown), mAb Y1D2 (Fig. 3A), or mAb Y2A11 (Fig. 3B). Both monoclonal antibodies recognize the 110-kD nuclear PEP antigen; often, but not always, mAb Y1D2, but not mAb Y2A11, recognizes sev- 
Figure 1. Distribution of PEP on polytene chromosomes from control larvae. Polytene chromosomes were squashed in an acetic acid-formaldehyde fixative solution onto a microscope slide and stained with mAb Y1D2, using an indirect immunofluorescence method (James and Elgin 1986). The chromosomes were photographed under phase-contrast and fluorescence illumination and mapped according to the designations of Lefevre (1976). (A) The phase-contrast picture of chromosomes from a puff stage 2 larva, where the intermolt puffs $68 \mathrm{C}$ and $90 \mathrm{BC},(\diamond)$, as well as the ecdysone puffs $42 \mathrm{~A}$ and $74 \mathrm{EF}(\mathbf{\Delta})$, are clearly visible. The nucleolus $(N)$ and chromocenter $(C)$ are also marked. $|B|$ The fluorescence picture of the same chromosomes shown in $A$, stained using $\mathrm{mAb}$ Y1D2. (A) The stained developmental loci; $(\diamond)$ those not stained. $(C)$ The phase-contrast picture of chromosome arm $3 \mathrm{~L}$ at puff stage 2. (A) The developmental loci that are active at this stage; $(\diamond)$ the intermolt puff $68 \mathrm{C}_{;}$(overlapping $\boldsymbol{\Delta} \Delta$ ) developmental puffs that will become active at later developmental stages (66B and 63E). (D) The fluorescence picture of the chromosome arm 3L (shown in $C$ ) stained with mAb Y1D2. The symbol designations are described in the legends $B$ and $C$ and denote the level of fluorescence due to PEP. specific staining. $|E|$ The fluorescence picture of the chromosome arm $3 \mathrm{~L}$ shown in $C$ and $D$, restained with affinity-purified antibodies specific for the carboxy-terminal domain of the largest subunit of RNA polymerase II (Fisher et al. 1989).
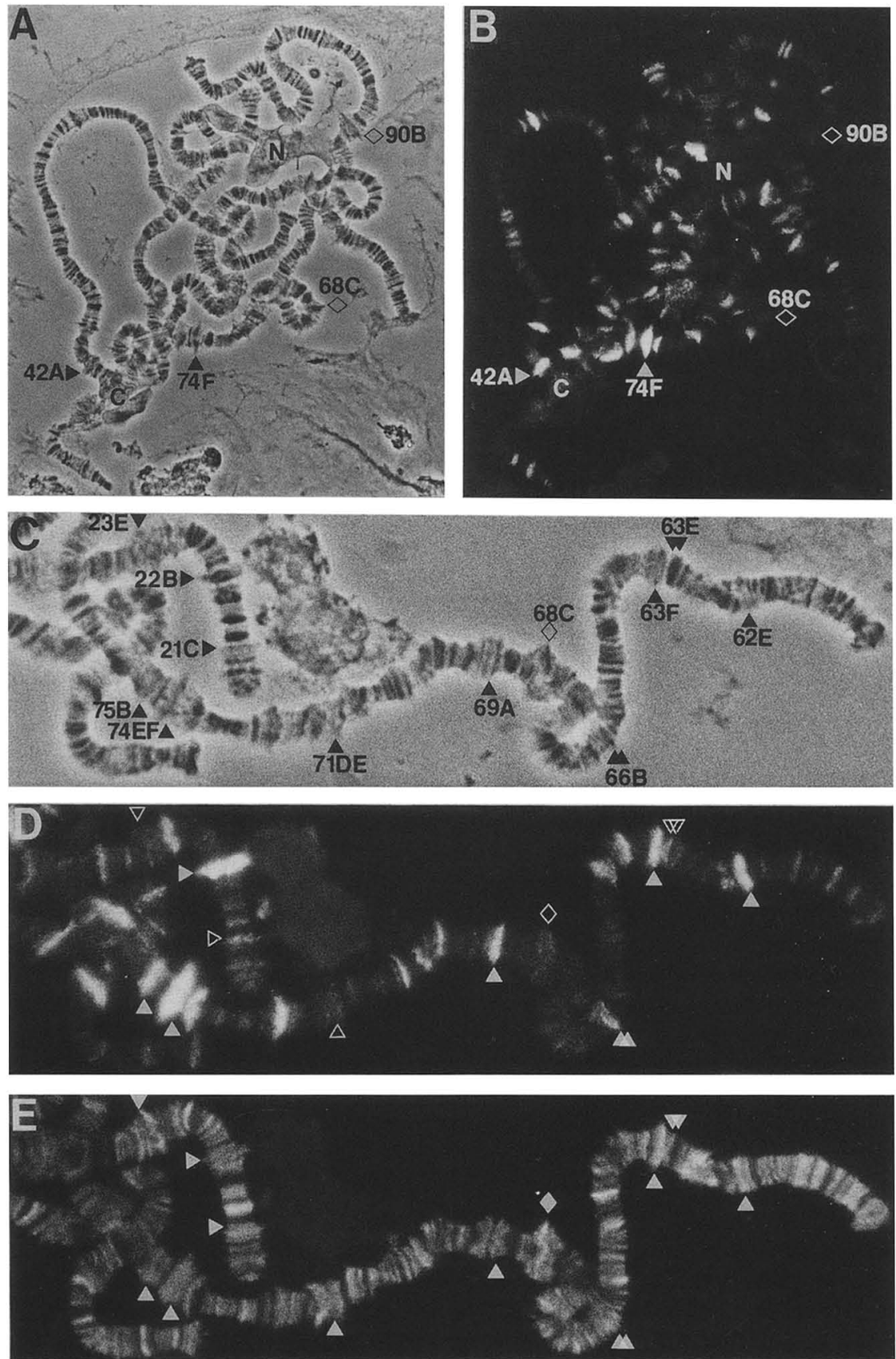

eral smaller polypeptides in the original extract, which are likely to be degradation products. The difference between the two epitopes is evident from the retention of the Y1D2 epitope on several smaller tryptic fragments, while in the same samples, the Y2All epitope is found only in the parental PEP antigen. Two prominent signals (20 and $24 \mathrm{kD}$ ) appear in all lanes containing trypsin, even in the absence of nuclear extract; these most likely arise from nonspecific recognition of the vast excess of trypsin in these samples. The filter incubated in TBS produced no signal.

The mAb Y1D2 was used to isolate a 1.8-kb Droso- phila DNA fragment from a $\lambda$ gt 11 expression library representing cDNAs from 0 - to 3-hr embryos (M. Phillip and D. Brutlag, pers. comm.). The partial cDNA fragment was shown to encode both the Y1D2 and Y2A11 epitopes from the PEP protein in the Western blot analysis shown in Figure 4. Bacterial lysates from a $\lambda$ lysogen strain carrying the 1.8 -kb cDNA fragment, both before and after induction, as well as Drosophila nuclear proteins and lysate from a lysogen carrying the unrelated HPl gene (James and Elgin 1986), were fractionated in an SDSpolyacrylamide gel (Fig. 4A), blotted to nitrocellulose, and probed with mAb Y1D2 (Fig. 4B). The monoclonal 
Table 1. Binding of the PEP protein to developmentally regulated puffs

\begin{tabular}{|c|c|c|c|c|c|c|c|c|c|}
\hline \multirow[b]{2}{*}{ Arm } & \multirow[b]{2}{*}{ Locus } & \multicolumn{2}{|c|}{ Stage 2} & \multicolumn{2}{|c|}{ Stage 6} & \multicolumn{2}{|c|}{ Stage 12} & \multicolumn{2}{|c|}{ Stage 18} \\
\hline & & $P$ & B & $P$ & B & $P$ & B & $\mathbf{P}$ & B \\
\hline \multirow[t]{8}{*}{$2 \mathrm{~L}$} & $21 \mathrm{C}$ & - & - & - & - & - & - & + & + \\
\hline & $21 \mathrm{~F}$ & - & - & \pm & \pm & - & - & - & - \\
\hline & $22 \mathrm{~A}$ & - & - & - & - & - & - & - & + \\
\hline & $22 B^{* *}$ & + & ++ & ++ & ++ & - & - & - & - \\
\hline & $22 \mathrm{C}$ & - & - & + & + & + & + & \pm & \pm \\
\hline & $23 E^{\star \star}$ & + & - & + & + & + & + & + & \pm \\
\hline & $25 \mathrm{AC}^{*}$ & + & - & \pm & \pm & + & \pm & - & \pm \\
\hline & $34 \mathrm{~A}$ & - & - & + & + & $\mathrm{X}$ & $\mathrm{X}$ & + & + \\
\hline \multirow[t]{10}{*}{$2 \mathrm{R}$} & $42 \mathrm{~A}$ & + & ++ & + & + & ++ & ++ & ++ & ++ \\
\hline & $46 \mathrm{~A}$ & - & - & + & ++ & $\mathrm{X}$ & $\mathrm{X}$ & - & - \\
\hline & $46 \mathrm{~F}$ & - & - & - & - & \pm & \pm & + & \pm \\
\hline & $47 \mathrm{~A}$ & - & - & - & - & + & \pm & - & \pm \\
\hline & $48 B$ & - & \pm & \pm & + & - & - & \pm & \pm \\
\hline & $52 \mathrm{~A}$ & - & - & \pm & + & - & - & $\mathrm{X}$ & $\mathrm{X}$ \\
\hline & $52 \mathrm{C}$ & - & \pm & \pm & \pm & + & + & $X$ & $\mathrm{X}$ \\
\hline & $55 \mathrm{E}$ & $\mathrm{X}$ & $\mathrm{X}$ & + & ++ & + & + & + & + \\
\hline & $58 \mathrm{BC}$ & \pm & + & + & ++ & - & - & $X$ & $\mathrm{X}$ \\
\hline & $60 \mathrm{~B}$ & - & - & - & - & $\mathrm{X}$ & $X$ & - & - \\
\hline \multirow[t]{11}{*}{$3 \mathrm{~L}$} & $62 \mathrm{E}$ & + & + & ++ & ++ & + & + & \pm & ++ \\
\hline & $63 \mathrm{E}$ & - & - & - & - & - & + & \pm & \pm \\
\hline & $63 F^{* *}$ & + & + & ++ & + & \pm & + & ++ & + \\
\hline & $66 \mathrm{~B}$ & + & + & \pm & \pm & + & + & + & + \\
\hline & $68 C^{\star}$ & ++ & \pm & ++ & \pm & + & - & + & - \\
\hline & $69 A$ & + & + & $\mathrm{X}$ & $\mathrm{X}$ & - & + & + & + \\
\hline & $71 \mathrm{DE}$ & + & \pm & + & ++ & $\mathrm{X}$ & $\mathrm{X}$ & + & - \\
\hline & $74 E F^{* *}$ & ++ & ++ & ++ & ++ & + & + & ++ & ++ \\
\hline & $75 \mathrm{~B}^{* *}$ & ++ & ++ & ++ & ++ & + & + & ++ & + \\
\hline & $75 \mathrm{CD}$ & - & - & $\mathrm{X}$ & $\mathrm{X}$ & $\mathrm{X}$ & $\mathrm{X}$ & \pm & - \\
\hline & $78 \mathrm{D}$ & - & - & ++ & ++ & + & + & + & + \\
\hline \multirow[t]{9}{*}{$3 R$} & $82 F$ & - & + & + & + & + & + & ++ & ++ \\
\hline & $85 \mathrm{D}$ & + & \pm & ++ & $+1+$ & $\mathrm{X}$ & $\mathrm{X}$ & + & $+1+$ \\
\hline & $85 \mathrm{~F}$ & + & ++ & ++ & ++ & + & + & $+t$ & ++ \\
\hline & $90 \mathrm{BC}^{\star}$ & ++ & - & - & - & ++ & - & ++ & - \\
\hline & 91D & - & - & \pm & + & \pm & \pm & + & - \\
\hline & $93 \mathrm{~F}$ & - & - & - & - & + & + & - & - \\
\hline & $95 \mathrm{~F}$ & - & - & + & + & $\mathrm{X}$ & $\mathrm{X}$ & + & \pm \\
\hline & $98 \mathrm{~F}$ & + & - & + & + & - & - & - & - \\
\hline & $100 \mathrm{DE}$ & - & + & - & - & \pm & + & + & + \\
\hline
\end{tabular}

(") Intermolt puffs; (**) early puffs; all others are late puffs. The puffing status of the developmental puffs used in this analysis is presented under the columns marked $P$; puffs were scored as very prominent $(++)$, clearly puffed $(+)$, slightly puffed $( \pm)$, or not puffed $(-1$. An $X$ denotes a puff that was not visible in the field. Two nuclei were averaged for stages 2 and 6 . Puffing stages were determined by comparison of the puffing patterns to the tabulations presented by Ashburner and Berendes (1978). The binding of PEP (columns marked B), or the level of fluorescence at a puff, was scored as intense $(++1$, clearly above background $(+1$, barely detectable above background $( \pm)$, or not detectable $(-)$. The $+/+$ designation in the binding column for locus 85D indicates that two distinct fluorescence signals were visible at this locus. The $\mathrm{X}$ chromosome was not scored.

antibody recognizes one major protein species of $110 \mathrm{kD}$, the PEP antigen, in the nuclear extract (Fig. 4B, lane 1), and three large polypeptides in the PEP lysogens (Fig. 4B, lanes 3 and 5), but nothing in the HP1 lysogen (Fig. 4B, lane 4). Although some low-level expression of the $\beta$-gal/PEP fusion protein occurs in the absence of IPTG (Fig. 4B, lane 3), the induction by IPTG is apparent by comparison (Fig. 4B, lane 5). The same nuclear and PEP lysogen extracts were probed also with mAb Y2A1l (Fig. $4 C)$. The Y2A11 epitope is present in the $110-\mathrm{kD}$ nuclear PEP antigen (Fig. 4C, lane 1) and in the largest of the induced $\beta$-gal/PEP fusion proteins, but not in the two smaller induced polypeptides (Fig. 4C, lane 3). Therefore, the 1.8-kb DNA sequence encodes two epitopes from the PEP antigen, confirming its origin in the Pep gene. This partial cDNA fragment was used to isolate a $2.7-\mathrm{kb}$ cDNA Drosophila clone from a second library made to optimize synthesis of full-length copies of mRNAs (Brown and Kafatos 1988). This longer clone was used for the analyses described below.

\section{The Pep gene maps to the cytological locus $74 F$}

The chromosomal site of the Pep gene was determined by in situ hybridization to polytene chromosomes of a biotin-labeled $2.5-\mathrm{kb}$ HindIII fragment from the cDNA clone. Signal was detected within the proximal portion of the puff at the cytological locus $74 \mathrm{~F}$ (Fig. 5), adjacent to the early ecdysone-responsive region. The puffing at this locus appears to be due to the vigorous ecdysone induction of the neighboring E74 early gene (Thummel et al. 1990), rather than the Pep gene (see below). Genomic Southern blot analyses (not shown) suggest that there is a single copy of the Pep gene covering no more than $8 \mathrm{~kb}$ of the chromosome at this site.

\section{The Pep gene is not regulated by ecdysone}

Transcripts from the Pep gene were examined at different developmental stages by probing a Northern blot containing poly $(\mathrm{A})^{+}$RNA from staged organisms with the cDNA probe used for the in situ hybridizations above. In every developmental stage, a single signal representing a transcript of $\sim 2.8 \mathrm{~kb}$ is visible (Fig. 6); the signal is enhanced, however, in the lanes containing samples from ovaries and 0 - to 3 -hr embryos. The loading controls for this filter representing transcripts from the ribosomal protein gene $r p 49$ (O'Connell and Rosbash 1984) indicate overloading in the lanes containing RNA from 4- to 12-hr embryos and third-instar larvae. From this analysis we conclude that maternal Pep gene transcripts are supplied to the embryo, and the level of $P e p$ gene transcripts decreases to a relatively constant level following embryogenesis. The abundance of Pep gene transcripts does not reflect the pulses of ecdysone that occur in mid-embryogenesis (Kraminsky et al. 1980) and in each larval instar (Hodgetts et al. 1977) but may be correlated with the presence of ecdysone in ovaries and the syncytial zygote (Richards 1981). In an additional experiment, a Northern blot filter containing RNA samples from isolated larval organs that had been exposed in vitro to ecdysone or to ecdysone plus cycloheximide was 
Figure 2. Distribution of PEP on polytene chromosomes from heat-shocked larvae. Larvae were maintained at $38^{\circ}$ for $40 \mathrm{~min}$ to induce the heat shock response before squashing and staining of their polytene chromosomes. The chromosomes were photographed and mapped as described in the legend to Fig. 1. $(A)$ The phase-contrast picture of chromosome arm $3 \mathrm{R}$, where the heat shock puffs at loci 87A, 87C, 93D, and $95 \mathrm{D}$ are clearly visible. $(B)$ The fluorescence picture of the same chromosome shown in $A$, stained using $\mathrm{mAb}$ Y1D2. $(\Delta \mid$ Puffs lacking PEP-specific staining; (A) symbols mark puffs displaying significant PEP-specific staining. (C) The phase-contrast picture of chromosome arm $3 \mathrm{~L}$, where the heat shock puffs at loci 63BC, $64 \mathrm{~F}, 67 \mathrm{~B}$, and $70 \mathrm{~A}$ are clearly visible. $(D)$ The fluorescence picture of the same chromosome shown in $C$, stained using $\mathrm{mAb}$ Y1D2. Symbols denote the level of fluorescence due to PEP-specific staining, as described in the legend to $B$.
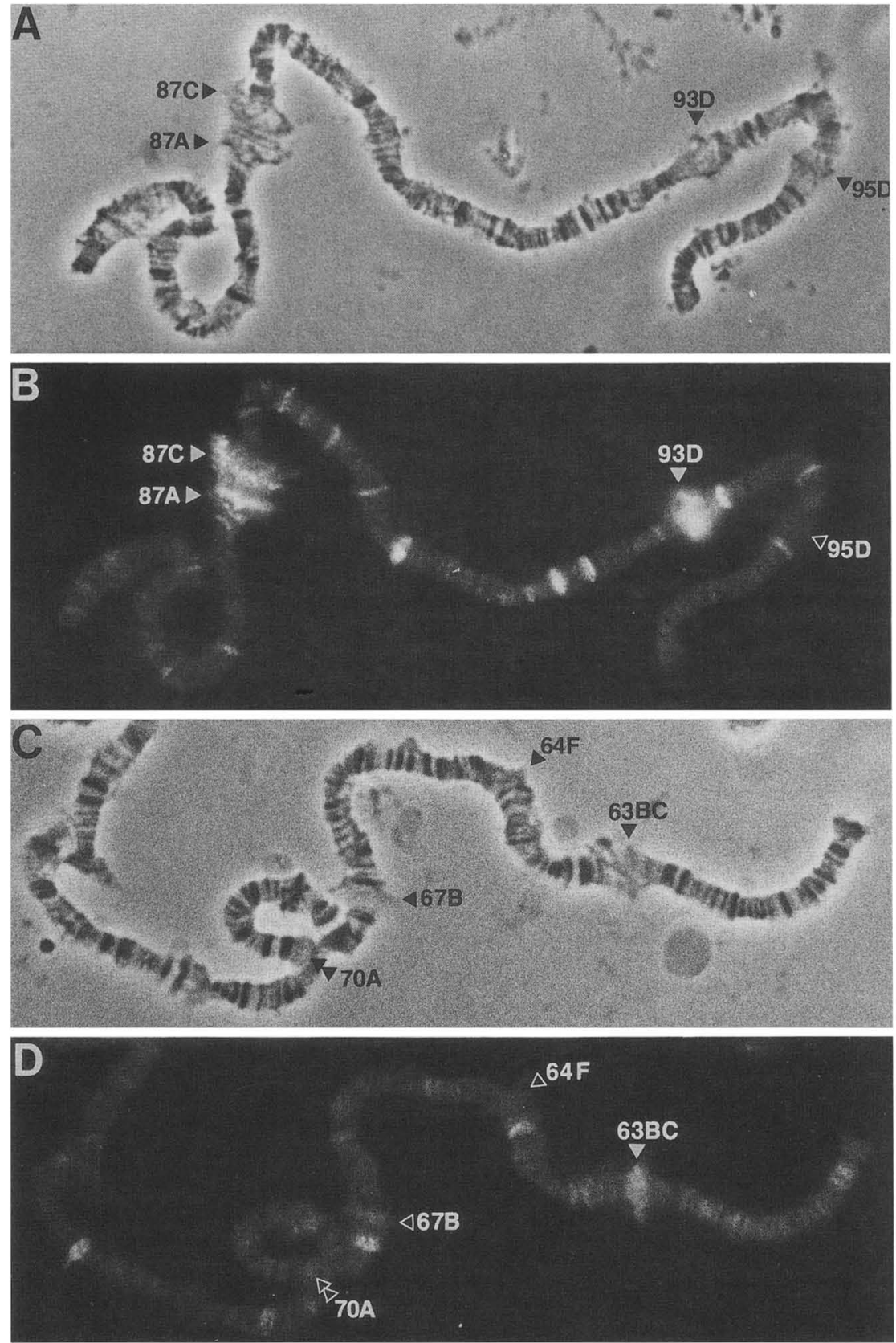

probed with the same Pep cDNA fragment; the treatments had no effect on Pep gene expression (not shown).

The PEP antigen contains numerous motifs suggesting nucleic acid interactions

For sequence analysis, the $2.7-\mathrm{kb}$ cDNA was subcloned into the BlueScript phagemid (Stratagene) in two overlapping pieces, one 2.5 - $\mathrm{kb}$ HindIII 5 '-terminal fragment and one 300-bp EcoRI 3'-terminal fragment. The nucleotide sequence was determined on each strand using nested deletions; an average of six readings per base pair position was compiled. The amino acid sequence derived from the primary nucleotide sequence predicts a molecular mass of 77,942 daltons for PEP (Fig. 7A), rather than the 110-kD figure deduced from its electrophoretic mobility. The discrepancy may arise as a consequence of the highly charged domains found in the sequence /see below) and/or PEP may be modified post-translationally. Because both ends of the clone contain only closed reading frames, the clone probably covers the entire proteincoding sequence, that is, to the amino terminus of the protein, but does not necessarily extend to the transcription start site (Hultmark et al. 1986). Several potential translation start sites are found within the first $200 \mathrm{nu}$ cleotides of open reading frame; of these, only the first 


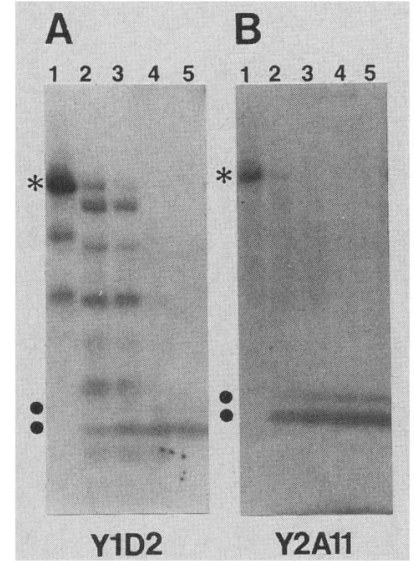

Figure 3. Epitope mapping of $\mathrm{mAbs} \mathrm{Y} 1 \mathrm{D} 2$ and $\mathrm{Y} 2 \mathrm{All}$. Drosophila nuclear extract was digested with increasing amounts of trypsin, and identical samples were fractionated by electrophoresis in an SDS-polyacrylamide gel; the polypeptides were transferred to nitrocellulose and probed with either TBS (not shown), mAb Y1D2, or mAb Y2A11. (A) Western blot analysis of the polypeptides probed with mAb Y1D2. (Lane 1) Drosophila nuclear proteins; (lanes 2-4) the same proteins digested for 45 min with 10,25 , or $50 \mu \mathrm{g}$ of trypsin/ml, (lane 5) trypsin alone $(50 \mu \mathrm{g} / \mathrm{ml}) .\left(^{*}\right)$ The position of the nuclear PEP antigen; $(0)$ two nonspecific signals that may arise from the excess of trypsin in these samples. $(B)$ A duplicate Western blot analysis using $\mathrm{mAb}$ Y2A11.

two, centered at nucleotides 218 and 297, possess flanking sequences that conform to the Drosophila start site consensus sequence, (A/C)AA/A/C)AUGG (Cavener 1987). The scanning model for translation (Kozak 1989) would suggest that the first AUG in the sequence, which represents a poor, but acceptable, match to the consensus, is likely to be the initiator codon for synthesis of PEP; however, the second site, in phase with the first, presents a perfect match to the consensus sequence and might be used. It is possible that multiple sites are functional, as has been shown for the glucocorticoid receptor (Miesfeld et al. 1986).

A number of interesting motifs are discernible within the deduced sequence for PEP:

1. The amino terminus of the protein consists of a region 166 amino acid residues in length, of which 40 residues $(24 \%)$ are glycine and 33 residues $(20 \%)$ are asparagine (both underlined in Fig. 7A). This segment is reminiscent of the carboxy-terminal glycine-rich regions that exist in the rat hnRNP Al protein (Cobianchi et al. 1986), the Drosophila Hrb98DE protein (Haynes et al. 1990), and nucleolin from several species (Caizergues-Ferrer et al. 1989), proteins all known to bind to RNA.

2. A second putative nucleic-acid binding segment, commencing with amino acid 215 , contains three zinc finger motifs (double underline in Fig. 7A) of the $\mathrm{X}_{2}$-Cys- $\mathrm{X}_{2}$-Cys- $\mathrm{X}_{10-12}-$ His- $\mathrm{X}_{5}$-His type, motifs found in many eukaryotic transcriptional activators (Johnson and McKnight 1989; Struhl 1989; Berg 1990) and in some RNA-binding proteins (Miller et al. 1985; Joho et al. 1990). The PEP fingers are distinctive in possessing five amino acid residues between the histidine residues rather than four (Fig. 7B), a motif found predominantly in Drosophila finger proteins (Wingender 1988); they are not of the type found in nuclear hormone receptors (Wingender 1988). The spacing of the fingers in PEP is unusual; most repetitive fingers in other proteins are separated by only 7-10 amino acid residues (Berg 1988; Lee et al. 1989).

3 . The segment from residues $396-630$ in the PEP protein spans two exceptionally acidic regions (boxed in Fig. 7A), which surround a fourth zinc finger of the type mentioned above (double underline in Fig. 7A). Acidic region 1 (79 residues in length) possesses 24 glutamic acid $(30 \%)$ and 11 aspartic acid $(14 \%)$ residues, with a net charge of -31 . Immediately preceding acidic region 1 there is a basic sequence, Lys-ArgLys-Lys-Lys-Pro-Val (overlined in Fig. 7A) similar to the nuclear localization signal found in the SV40 large $T$ antigen, Pro-Lys-Lys-Lys-Arg-Lys-Val (Dingwall and Laskey 1986). Throughout most of this acidic region, alanine residues appear every five to six residues. Zinc finger 4 occurs midway between the acidic regions. Acidic region 2 (90 residues in length) possesses 34 glutamic acid $(38 \%)$ and 9 aspartic acid

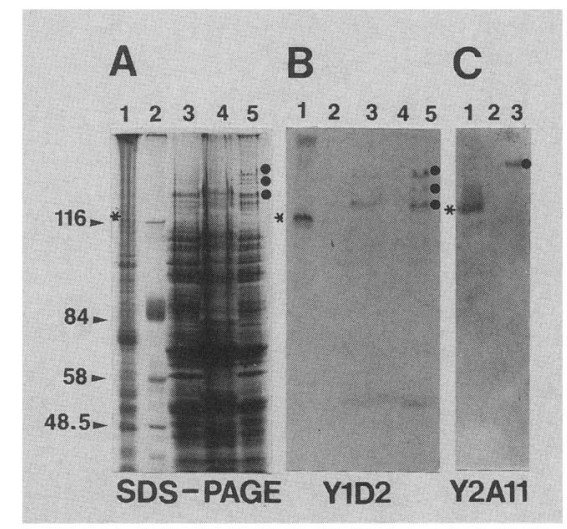

Figure 4. Western blot analysis of fusion proteins produced in $\lambda$ gt 11 lysogens. The 1.8-kb Drosophila DNA fragment identified from a $\lambda g t 11$ expression library with MAb YlD2 was used to produce an IPTG-inducible $\beta$-gal/PEP fusion protein in $E$. coli strain Y1089. A similar $\lambda$ lysogen containing the gene for a fusion protein with the unrelated Drosophila heterochromatin protein HPl (James and Elgin 1986) was used as a control. $(A)$ SDS-polyacrylamide gel electrophoresis of Drosophila nuclear proteins (lane 1), molecular weight markers (lane 2), uninduced PEP lysogen proteins (lane 3), induced HP1 lysogen proteins (lane 4), and induced PEP lysogen proteins (lane 5), stained with Coomassie blue. The sizes of the molecular mass markers are given in kilodaltons (left), asterisks mark the position of the nuclear PEP protein, and dots mark the positions of induced fusion proteins. $(B)$. Western blot analysis of the proteins in the gel in $A$, probed with mAb Y1D2. $(C)$ Western blot analysis of Drosophila nuclear proteins (lane 1), molecular mass markers (lane 2), and proteins from the induced PEP lysogen (lane 3), using mAb Y2A11. 
Figure 5. Localization of the Pep gene on polytene chromosomes. Polytene chromosomes from third-instar larvae were squashed onto a microscope slide in acetic acid and probed with the $2.5 \cdot \mathrm{kb}$ HindIII fragment from the $2.7-\mathrm{kb}$ cDNA clone. The only signal on the chromosomes was mapped to the proximal portion of the ecdysone-responsive puff at locus $74 \mathrm{~F}$, by reference to the designations of Lefevre (1976).

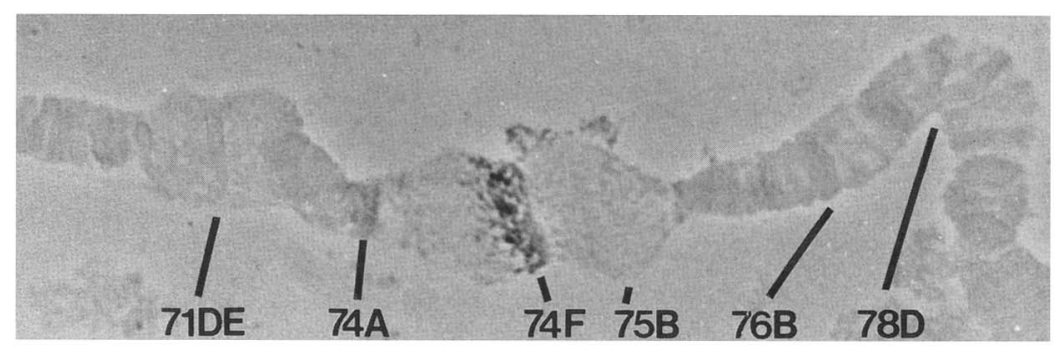

$(10 \%)$ residues, with a net charge of -43 ; interestingly, a second stretch of basic residues, Arg-Lys-LysArg-Lys-Val, loverlined in Fig. 7A) resides next to acidic region 2 , in a position analogous to the basic sequence preceding acidic region 1 . Several functions have been observed for highly acidic domains in other chromosomal proteins (Earnshaw 1987), including transcriptional activation (Ptashne 1988), recognition of histones for polyubiquitination (Sung et al. 1988), or nucleosome assembly/disassembly (Dingwall et al. 1987).

4. The carboxy-terminal 80 amino acids of PEP are rich in alanine $(34 \%)$, proline $(24 \%)$, and serine and threonine ( $15 \%$ combined).

5. The Pep cDNA clone contains 377 nucleotides beyond the first termination codon, ending in the sequence AAUAAA, the consensus polyadenylation signal (Proudfoot and Whitelaw 1988). Because the cDNA library was constructed by primer extension from the poly (A) tails of mRNAs, the existence of this

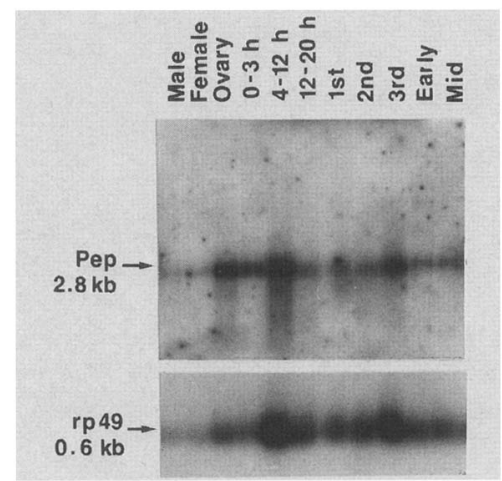

Figure 6. Northern blot analysis of PEP expression during development. Samples of poly $(\mathrm{A})^{+}$RNA $(1 \mu \mathrm{g})$ from the stages indicated (adult males and female carcasses, ovaries, 0 - to 3 -hr embryos, 4- to 12-hr embryos, 12- to 20-hr embryos, first-instar larvae, second-instar larvae, third-instar larvae, early pupae, and mid-stage pupae) were fractionated electrophoretically and transferred to a nylon membrane as described by Haynes et al. (1990). The RNA was probed with a labeled $2.5-\mathrm{kb}$ HindIII fragment from Pep cDNA. The size of the Pep transcript was deduced by comparison to RNA size markers. The loading controls for this filter represent transcripts from the ribosomal protein gene rp49 (O'Connell and Rosbash 1984) and indicate overloading of the samples from 4- to $12 \mathrm{hr}$ embryos and thirdinstar larvae. canonical sequence at the very end of the clone, rather than 20-30 nucleotides upstream, suggests that the clone arose by priming from an adjacent $\mathrm{A} /$ $T$-rich sequence. Within the $3^{\prime}$-untranslated sequence is found a nearly perfect match to a 450 -bp genomic sequence reported previously from locus $74 \mathrm{~F}$; the genomic sequence was reported to hybridize to a $2.8-\mathrm{kb}$ ecdysone-inducible transcript in $\mathrm{KC}$ cells (Moritz et al. 1984). That genomic sequence contains 29 nucleotides not found in our cDNA, suggesting strain-specific polymorphism. The $74 \mathrm{~F}$ genomic sequence was cloned from Canton-S flies, while the cDNA library used here was prepared from the Oregon-R strain. The genomic sequence also contains an A-rich stretch downstream of the AAUAAA motif, which may have served as the start of the primer extension reaction during construction of the cDNA library. The overlap with the $74 \mathrm{~F}$ sequence and the identity of the transcript sizes suggest that the gene fragment reported by Moritz et al. (1984) is from the gene we have isolated. Thus, from the prior localization of the $74 \mathrm{~F}$ sequence on the chromosomal walk from this region (Thummel et al. 1990), we know that the Pep gene probably resides $15-20 \mathrm{~kb}$ in the proximal direction from the ecdysone-responsive E74 gene.

6. It is interesting to note the linear duplication of segments in the carboxy-terminal half of PEP, that is, the repetition of zinc finger, nuclear localization signal, and acidic domain. A search of Genbank version 63 for proteins found that the PEP sequence is unique.

\section{Discussion}

The chromosomal distribution of the PEP antigen suggests a tight correlation between the presence of this protein and transcription at a defined subset of active loci. The pattern changes with changes in the developmental program or following heat shock. The pattern is more selective than others reported at active loci [topoisomerase I (Fleischmann et al. 1984), RNA polymerase II (Sass 1982; Weeks et al. 1982), hnRNP proteins (S.A. Amero and A.L. Beyers, unpubl.), and snRNP proteins [Sass and Pederson, 1984; S.A. Amero et al., in prep.)], as staining does not appear at most intermolt puffs or interbands, or at certain heat shock-induced puffs. The strong correlation between PEP and active hormonally regulated loci argues for a role for the protein in the process of ecdysone-mediated transcriptional activation. 
203 AAACCCATCAMATTATGGTCAGCGTAMAGGTCAACGGAMATCCGCAGAATTCGTTTAGTGMATAACGCAMGGTCAACGGCAMCATGGCTTTCCGTGGTAAC

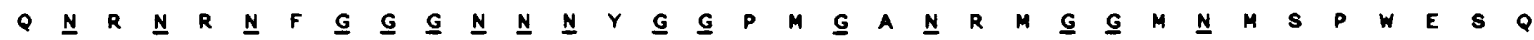

305 CAGAACCGCAACCCGCAATTTTGGAGGTGGCAACAACAÁCTATGGTGGACCCATGGGCGCCAMCCGCATGGGCGGTATGMACATGTCGCCTTGGGATCGCAG

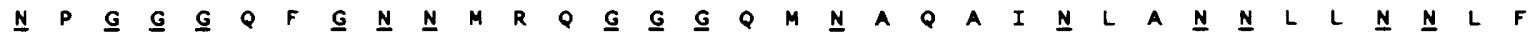

407 AATCCCGGCGGCGGACAGTTTGGTAACAACATGCGACAGGGTGGCGGTCAGATGAACGCCCAGGCCATCAACTTGGCCAACAATCTGCTGAACAATCTGTTC

$\begin{array}{llllllllllllllllllllllllllllllllllll}R & N & P & N & P & P & S & L & L & D & L & P & R & G & G & G & G & M & G & N & R & N & Q & R & G & G & P & M & V & S & R & G & G & G\end{array}$

509 AGGAACCAGAATCCACCATCGCTTCTCGACTTGCCCCGCGGCGGCGGTGGCATGGGAMATCGCAACCAACGTGGTGGCCCGATGGTCAGTCGCGGCGGCGGT

$\begin{array}{llllllllllllllllllllllllllllllllllll}A & G & \underline{N} & R & L & \underline{N} & \underline{N} & R & R & \underline{G} & Q & G & \underline{G} & \underline{G} & F & Q & N & R & G & A & T & G & S & \underline{G} & P & K & P & P & P & K & Q & \underline{G} & \underline{G} & \underline{G}\end{array}$

611 GCCGGCAATTCGTCTCAATAACCGTCGTGGCCAGGGAGGTGGCTTCCAMAATCGTGGCGCCACTGGTAGTGGACCCAAGCCCCCGCCAAAGCAGGGCGGCGGC

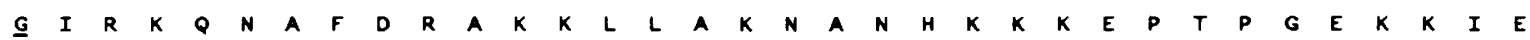

713 GGTATTCGCAAGCAAAATGCTTTTGATCGTGCCAAGAAACTTTTGGCTAAAAATGCCAACCATAMAMAGAAGGAACCCACTCCTGGCGAAAAGAAAATCGAG

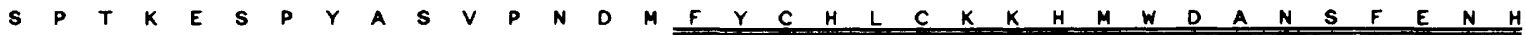

815 AGCCCTACCAAGGAGTCTCCATACGCTAGTGTGCCGAACGACATGTTCTACTGTCATCTGTGCAAGAAGCACATGTGGGATGCAACTCTTTCGAGAACCAC

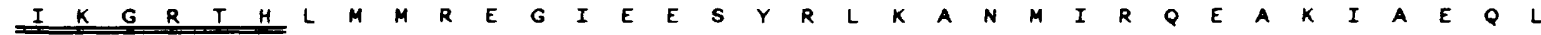

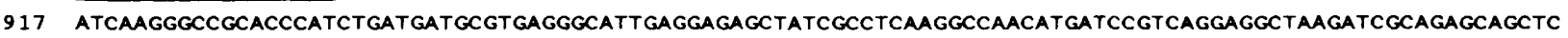

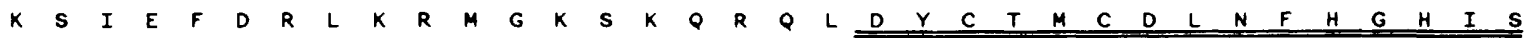

1019 AAGTCGATCGAGTTTGACCGCTTGAAGCGCATGGGCAAAAGCAAGCAGCGTCAGCTGGACTACTGCACCATGTGCGACCTGAACTTCCATGGTCACATCTCG

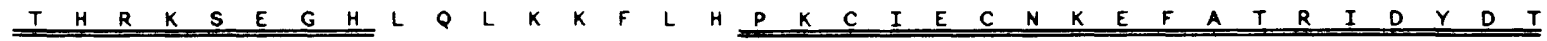

1121 ACCCATCGCAAGTCGGAGGGACATTTGCAGCTGAAGAAGTTCTTGCACCCCAAGTGCATTGAGTGCAACAAGGAGTTCGCCACTCGCATTGACTACGATACT

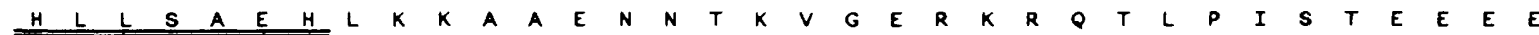
1223 CATCTGCTGTCCGCCGAGCATCTGAAGAAGGCTGCCGAGAACAACACCAAGGTGGGTGAGCGCAAGCGCCAGACCTTGCCCATCAGCACCGAAGAAGAGGAG

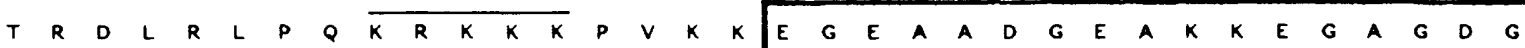
1325 ACCCGCGATTTGCGCCTGCCCCAGAAGCGCAAGAAGAAGCCGGTCAMGAAGGAGGGCGAAGCAGCCGATGGCGAGGCTAAGAAGGAGGGTGCCGGCGATGGC

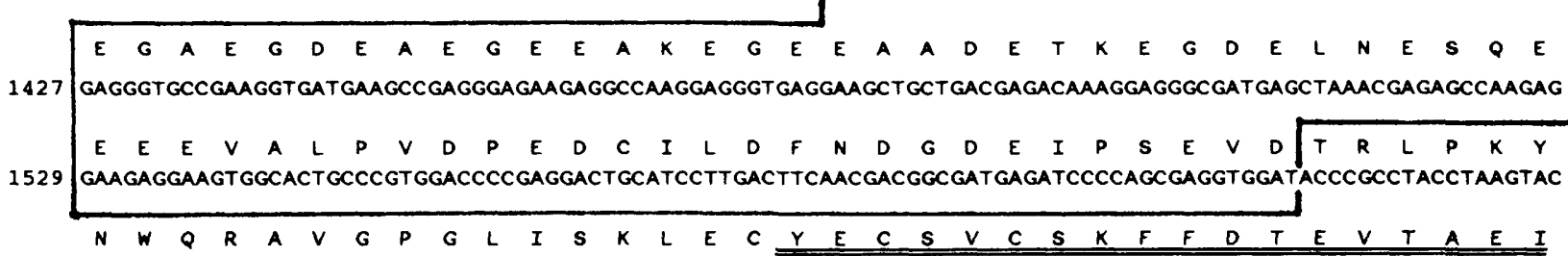
1631 AACTGGCAGCGTGCTGTCGGTCCCGGTCTGATCTCCAAGCTGGAGTGCTATGAGTGCTCGGTGTGCAGCAAGTTCTTCGACACCGAGGTGACCGCCGAGATT

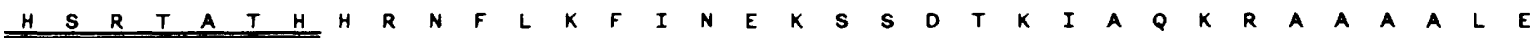
1733 CACTCCCGTACGGCGACTCATCACCGCAACTTCTTGAAGTTTATCAACGAGAMATCAAGCGATACCAAGATCGCACAGAAGCGCGCAGCTGCCGCCCTGGAG

E N E R K K R K V E E E A E A P A A E G A A E E 1835 GAGAATGAGCGTAAGAAGCGCAAGGTTGAGGAGGCAGAGGCTCCGGCTGCCGAGGGCGCAGCCGAGGAAACCACCGAAGGCGCTGAGGGTGAGCTGTACGAT

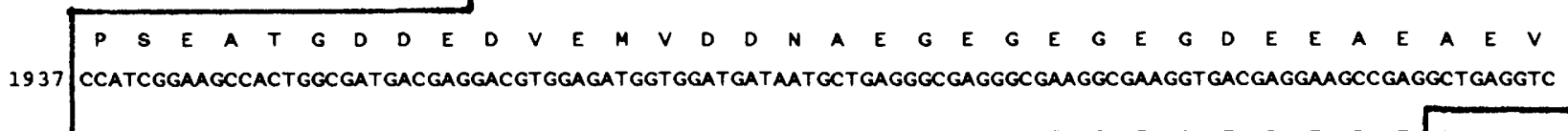
E E D G A G Q D N G E E E M E A Q E E E G Q E G E Q E P E P E P A P 2039 GAGGAAGATGGCGCCGGCCAGGACAACGGCGAAGAGGAGATGGAAGCCCAGGAGGAAGAGGGTCAGGAGGGCGAGCAAGAGCCCGAACCTGAGCCAGCTCCA

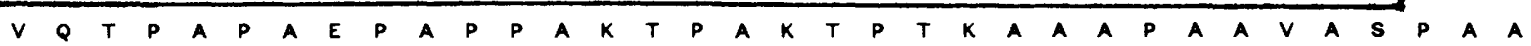

2141 GTCCAAACTCCTGCCCCGGCTGAACCTGCACCACCAGCCAAGACCCCAGCCAAGACTCCGACCAAGGCAGCTGCTCCAGCCGCTGTTGCCAGTCCCGCAGCT

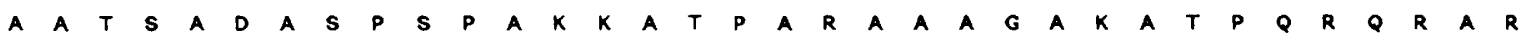
2243 GCGGCAACGTCGGCAGACGCCTCTCCATCTCCGGCCAAGAAGGCAACGCCTGCTCGCGCTGCCGCCGGAGCCAAGGCCACGCCGCAGCGACAACGCGCCCGC

G $R Y Y N R Y$

2345 GGTCGCTACAATCGCTACTAAGTAGACGTCGAAGgAATTCGTAATTTAACATAACATAAACCTTAATATACAAGAAAAAATTTACATTCACGCCCAGGAGGA

Figure 7. (See following page for legend.) 


\begin{abstract}
2447 GGATGAAGAAAGAACAGATCAAATCGATCTCTTCCCGCAATTTGACATTTGCATCCCAATTTGCATATACACTGAATGAATGGAAACTGAGAAGAAGACGGT
2549 CAACTTTTAGTTGAAACAGTTGAATATATTGTACGACGAAGCTTCTTGAAACTGACGAGGGAGAACACAAACAAGTTAATTGAATCGAGAATCGTATTTCCT
\end{abstract}

2651 ACCCGATTCCCCCCTCACAGAACGCATACCATGCCAGCCAGCGAACCAACCATTCAACTTATGTAATCATATAAATTCTATAATAAAC

B

Figure 7. Sequence of the Pep cDNA and protein. $(A)$ The sequence of the $2.7-\mathrm{kb} \mathrm{cDNA}$ from the Pep gene was compiled using the ODBUTIL program (Staden 1980) and translated using the DM program (Mount and Conrad 1986). Within the deduced protein sequence are found the following motifs: a glycine (G)- and asparagine (N)-rich segment (glycines and asparagines are underlined), four zinc finger motifs (double-underlined), two acidic regions (boxed areas), two nuclear localization-type signals (overlined), and an alanine (A)- and proline (P)-rich carboxyl terminus. The overlap with the $74 \mathrm{~F}$ genomic sequence (Moritz et al. 1984) is underlined in the 3 '-untranslated Pep cDNA sequence. The probe used for the in situ hybridization and Northern blot analyses is indicated between the arrowheads. $(B)$ Alignment of zinc finger motifs in PEP with the consensus finger sequence from Drosophila proteins (Harrison and Travers 1990). The conserved pairs of cysteine $(\mathrm{C})$ and histidine $(\mathrm{H})$ residues are shaded and underlined.
PEP FINGER MOTIFS:

FYCHLCKKHMWDANSFENHIKGRTH DYCTMCDLNFHGHIST - - HRKSEGH PKCIECNKEFATRI DYDTHLLSAEH YECSVCSKFFDTEVTAEIHSRTATH DROSOPHILA CONSENSUS: $F \cdot \underline{C} . \underline{C} \cdot K \cdot F \ldots . F \cdot \underline{H} \underbrace{L}_{Y} \cdot \underline{H}$
The additional sites in the PEP distribution pattern suggest a function(s) for the protein in other activation systems as well.

Our observations complement the regulatory model proposed by Ashburner and his colleagues to accommodate the salient features of the larval/prepupal ecdysone system (Ashburner et al. 1974; Ashburner 1990). The model suggests that the genes within the early puffs are directly activated by ecdysone in conjunction with the ecdysone receptor. Activation of the early puffs does not require de novo protein synthesis but is strictly dependent on the presence of hormone (Ashburner 1974). Several of the early genes have been cloned and shown to respond directly to ecdysone (Burtis et al. 1990; Segraves and Hogness 1990; Thummel et al. 1990), as expected. Our finding of PEP on the early puffs, in the early puffing stages, introduces an additional factor to this process and suggests that PEP is recruited into early gene activation or expression. Second, in the Ashburner model, activation of the late genes is proposed to involve the products of the early genes (Ashburner 1974); this process is dependent on de novo protein synthesis. This aspect of the model has been confirmed recently, since the E74 protein, the product of the E74 early gene, has been localized on the late puffs (Umess and Thummel 1990). Our studies add a new component to this level of ecdysone-mediated gene expression as well, because PEP is not the product of a classic early gene but is found on the late puffs. Thus, the evidence suggests that PEP is involved in ecdysone-mediated gene expression of both the early and late genes in the Ashburner model, and that PEP binding at these sites is regulated, perhaps indirectly, by ecdysone.

The known properties of the Pep gene and its protein product-its pattern of expression, sequence motifs, and recruitment to active complexes - would be expected of a "coactivator" transcription factor, as described by Lewin (1990), a protein that adapts the transcriptional apparatus to specific induction mechanisms, in this case, the ecdysone induction mechanism. In this scenario,
PEP may communicate between the basal transcription factors and the ecdysone receptor, or early gene products, using zinc fingers to contact specific DNA sequences and acidic domains for protein-protein contacts. The protein may perform a similar function in other activation systems, possibly at the minor sites in the PEP distribution pattern. Our observations to date-the tight coupling with transcription, intense staining within a puff, and certain sequence motifs-are also consistent with the possibility that PEP is a component of a ribonucleoprotein complex, and we note the ability of the transcription factor IIIA, also a zinc finger protein, to contact both DNA and RNA (Miller et al. 1985). In this context, PEP may communicate between the hormonally activated transcription complexes, containing the ecdysone receptor or the early gene products, and the RNA packaging and processing machinery, containing the transcripts of the early and late genes. It will clearly be exciting to explore further the functions of this unique protein.

\section{Methods and materials}

\section{Generation of monoclonal antibodies}

Drosophila melanogaster (Oregon- $\mathrm{R}$ ) strains were maintained as a laboratory population in a $25^{\circ} \mathrm{C}$ growth chamber, as described by Elgin and Miller (1977). Embryos collected at staged intervals were frozen and stored at $-80^{\circ} \mathrm{C}$. Nuclei were isolated according to the procedures described by Mayfield et al. (1978) including centrifugation through a sucrose cushion. Nuclear proteins from $\sim 50$ grams of embryos $(6-12 \mathrm{hr})$ were extracted by homogenization in a Thomas size B homogenizer in $0.2 \mathrm{~mm}$ EDTA ( $\mathrm{pH} 8.0$ ), and preboiled RNase $\mathrm{A}$ was added to a final concentration of $1 \mu \mathrm{g} / \mathrm{ml}$. The suspension was incubated at $37^{\circ} \mathrm{C}$ for $30 \mathrm{~min}$; nuclei were then pelleted by centrifugation at $16,500 \mathrm{~g}$ in a Sorvall $\mathrm{HB}-4$ rotor for $10 \mathrm{~min}$ at $4^{\circ} \mathrm{C}$. All buffers used for homogenizing embryos, isolating and digesting nuclei, and extracting nuclear proteins contained $5 \mu \mathrm{g}$ leupeptin $/ \mathrm{ml}$, $0.2 \mathrm{Ti}$ units aprotinin/ml, and $0.1 \mathrm{~mm}$ phenylmethylsulfonyl fluoride (PMSF) (all from Sigma) to inhibit endogenous proteases. The supernatant containing EDTA-soluble nuclear pro- 
teins was dialyzed against 3 liters of $0.2 \mathrm{~mm}$ EDTA ( $\mathrm{pH} 8.0$ ), 0.1 $\mathrm{mM}$ PMSF for $3 \mathrm{hr}$ in the cold room and lyophilized.

Nuclear proteins were fractionated in Triton/acetic acid/ urea-polyacrylamide gels, and proteins in gel bands were used for immunization of BALB-c mice as described by Amero et al. (1988). Fusions of spleen cells and myeloma cells, production of hybridoma cell lines, and screening for positive hybridomas were conducted as described by James and Elgin (1986), following the procedures of Galfré and Milstein (1982).

\section{Epitope mapping and Western blot analyses}

Peptide mapping experiments were conducted by incubating $120 \mu \mathrm{l}$ of EDTA nuclear extract in the presence of increasing concentrations of trypsin (Boehringer Mannheim Biochemicals), either 10,25 , or $50 \mu \mathrm{g} / \mathrm{ml}$ in $125 \mathrm{~mm}$ Tris- $\mathrm{HCl}$ (pH 6.8), 1\% SDS, and $7.5 \%$ glycerol (after the procedure of Cleveland et al. 1977) at $37^{\circ} \mathrm{C}$ for $45 \mathrm{~min}$. The digestions were stopped by the addition of SDS to a final concentration of $2 \%$ and of $\beta$-mercaptoethanol to $166 \mathrm{~mm}$; the samples were boiled, and identical aliquots were loaded onto $12 \%$ SDS-polyacrylamide gels $(30 \%: 0.4 \%)$, as described by Laemmli (1970). For Western blot analyses, proteins were transferred from gels to nitrocellulose filters and probed as described by James and Elgin (1986). Clarified ascites fluid diluted $1: 20$ with blocking solution was used as the primary antibody, and ${ }^{125}$ I-labeled anti-mouse secondary antibody $\left[\mathrm{F}\left(\mathrm{ab}^{\prime}\right)_{2}\right]$ fragment (Amersham Corp.) was used at a dilution of $1: 500$ in blocking buffer. The filters were exposed overnight to preflashed Kodak X-Omat film at $-80^{\circ} \mathrm{C}$ with an intensifying screen.

\section{Screening cDNA libraries}

The $\lambda g t 11$ cDNA expression library, subcloned from the original $\lambda$ gt 10 library at the EcoRI sites (M. Philip and D. Brutlag, pers. comm.|, was screened with mAb Y1D2, using essentially the procedure of Huynh et al. (1985), as described by James and Elgin (1986). However, repeated screening attempts suggested an instability of the Pep clone in this vector, so the primary screen was performed at a dilution of $9 \times 10^{5}$ plaques on ten 150-mm Luria broth (LB)/ampicillin plates, using Escherichia coli strain Y1088. Twenty-five positive plaques from the primary screen were rescreened by Western blot analysis of the proteins produced in a high-titer 2 -ml minilysate of $E$. coli strain Y 1088 grown at $37^{\circ} \mathrm{C}$ in the presence of IPTG for $6 \mathrm{hr}$ (Silhavy et al. 1984); three isolates produced positive signals. One phage with a $1.8 \mathrm{-kb}$ insert was chosen for further analysis.

A $\beta$-galactosidase-PEP fusion protein was expressed in $E$. coli strain Y1089 lysogenized with the phage insert, following the procedures of Huynh et al. (1985). Following temperature shock and induction with IPTG, the bacterial cells /from 100-ml cultures) were collected by centrifugation, resuspended in $10 \mathrm{~mm}$ Tris- $\mathrm{HCl}(\mathrm{pH} \mathrm{7.5)}$, and frozen in liquid nitrogen. For protein analysis, the samples were fractionated in a 7\% SDS-polyacrylamide gel for Western blot analysis.

The 1.8-kb Pep insert was gel-purified by GeneClean (BIO 101), labeled with $\left[\alpha^{-32}\right.$ P]dATP (Amersham Corp.) by random priming (Feinberg and Vogelstein 1983), and used to screen a second cDNA library from 8- to 12 -hr embryos (Brown and Kafatos 1988). One-tenth the complexity of the library (and therefore $3 \times 10^{4}$ colonies/ was screened, and seven positive clones were isolated. The inserts in the pNB40 vector ranged in size from 1.7 to $2.7 \mathrm{~kb}$; the clone containing the $2.7-\mathrm{kb}$ insert, designated p3221, was chosen for further analysis.

\section{In situ hybridization}

Salivary glands were dissected from third instar larvae in $45 \%$ acetic acid, and polytene chromosomes were squashed onto subbed microscope slides as described by Pardue (1986). The 2.5-kb HindIII fragment from p3221 was isolated by GeneClean (BIO 101), labeled with biotin-UTP (Bethesda Research Laboratories) by random priming (Feinberg and Vogelstein 1983), and hybridized as described by Pardue (1986). The signal was visualized using the DNA Detection System from Bethesda Research Laboratories.

\section{Northern blot analysis}

The developmental Northern filter reported by Haynes et al. (1990) was reprobed with the $2.5-\mathrm{kb}$ HindIII fragment from the Pep cDNA.

The fragment was purified from agarose gels by GeneClean (BIO 101) and labeled with $\left[\alpha^{-32} \mathrm{P}\right] \mathrm{dATP}$ (Amersham Corp.) by random priming (Feinberg and Vogelstein 1983). A total of $1 \times 10^{9} \mathrm{cpm}$ was included in the hybridization, performed in the solutions recommended by Maniatis et al. (1982). The hybridization reaction was allowed to incubate for $24 \mathrm{hr}$ at $65^{\circ} \mathrm{C}$.

The filter was washed twice in $2 \times \mathrm{SSC}, 0.1 \% \mathrm{SDS}$, at room temperature, and twice in $0.2 \times \mathrm{SSC}, 0.1 \% \mathrm{SDS}$, at $60^{\circ} \mathrm{C}$. The filter was air-dried for $15 \mathrm{~min}$, covered with plastic wrap, and exposed to Kodak X-Omat AR film at $-80^{\circ} \mathrm{C}$ with an intensifying screen.

\section{Sequence analysis}

The insert in p3221 was subcloned in two pieces into the BlueScript phagemid for sequence determination. One $2.5-\mathrm{kb}$ HindIII fragment covers the $5^{\prime}$ end of the gene, extending into the pNB40 vector, and one 300-bp EcoRI fragment overlaps $\sim 50 \mathrm{bp}$ of the HindIII fragment and extends to the EcoRI site $20 \mathrm{bp}$ into the vector. These insert fragments were gel-purified by GeneClean (BIO 101) and cloned into the appropriate sites of BlueScript Plus phagemid (Stratagene, La Jolla, CA) in E. coli BB4 strain. Each orientation of each insert was isolated.

A series of nested deletions in each strand was created using exonuclease III and S1 nuclease (both from Boehringer Mannheim Biochemicals) for both the p3221 and $\lambda$ gt11 plasmids. Prior to ligation with T4 DNA ligase (Boehringer Mannheim), the ends of the deletions were filled in using Klenow fragment (Bethesda Research Laboratories) and nucleoside triphosphates. VCS-M13 helper phage for making single-stranded templates, dideoxynucleotides, primers, and Sequenase enzyme for sequencing reactions were all obtained from Stratagene. dATP labeled with ${ }^{35} \mathrm{~S}$ was purchased from Amersham. Several primers were synthesized by the University of Virginia Protein and Nucleic Acid Research Facility.

The contiguous sequences were assembled, and consensus sequences were computed using the ODBUTIL program (Staden 1980). The consensus sequence was translated into protein sequence using the DM program (Mount and Conrad 1986). The PEP protein sequence was compared to Genbank using the FASTP program (Pearson and Lippman 1988). The sequences obtained for the $\lambda \mathrm{gt} 1 \mathrm{l}$ and the p3221 inserts are identical, except for the presence of $58 \mathrm{bp}$ on the amino-terminal side of the $\lambda$ gt 11 insert, which is missing from the p3221 insert.

\section{Immunofluorescence assays}

Immunofluorescence analyses of polytene chromosomes were conducted by the methods of Silver and Elgin (1977), as modi- 
fied by James and Elgin (1986). Polytene chromosomes were squashed in a $45 \%$ acetic acid- $3.7 \%$ formaldehyde fixative solution. Antibody Y1D2 was used as a neat hybridoma supernatant; affinity-purified goat antibodies specific for the carboxyterminal domain of the largest subunit of RNA polymerase II (Fisher et al. 1989) were diluted 1: 100 in blocking buffer. Antimouse FITC-conjugated antibody and anti-goat FITCconjugated antibody were both obtained from ICN Immunobiologicals and diluted $1: 1000$ and $1: 300$, respectively. For restaining, the coverslips were flipped off the chromosomes with a razor blade, and the slides were washed three times in TBS at room temperature.

The chromosomes were photographed through a Leitz Orthomat fluorescence microscope using Kodak Tri-X film. Pictures were printed using high-contrast filters on Kodak Polycontrast paper. Developmental stages were determined by comparison of the puffing patterns to those in Table 1 of Ashburner and Berendes (1978).

\section{Acknowledgments}

We are truly indebted to T.C. James, Paul Adler, and Bob Kadner for guidance and assistance, to Jae Moon Lee and Amo Greenleaf for the provision of anti-pol II antibodies, to Susan Haynes, Felix Karim, and Carl Thummel for assistance with the Northern blot analyses, to Valerie Dietrich and Jack Diani for technical assistance, and to Keith Yamamoto for suggestions and advice. This work was supported by National Institutes of Health (NIH) grant GM39271 to A.L.B., NIH grant GM31532 to S.C.R.E., and NIH grant 5-S07-RR05431-28, grant IN 149F from the American Cancer Society, and March of Dimes grant 1-1200 to S.A.A. A.L.B. is the recipient of an American Cancer Society Faculty Research Award. Sequence data described in this paper have been submitted to EMBL/GenBank Data Libraries under accession number X56689.

The publication costs of this article were defrayed in part by payment of page charges. This article must therefore be hereby marked "advertisement" in accordance with 18 USC section 1734 solely to indicate this fact.

\section{References}

Amero, S. A., T.C. James, and S.C.R. Elgin. 1988. Raising antisera to proteins in gel bands. Methods Mol. Biol. 3: 355-362.

Ashburner, M. 1970. Patterns of puffing activity in the salivary gland chromosomes of Drosophila. Chromosoma 31: 356376.

- 1974. Sequential gene activation by ecdysone in polytene chromosomes of Drosophila melanogaster. II. The effects of inhibitors of protein synthesis. Dev. Biol. 39: 141157.

- 1990. Puffs, genes, and hormones revisited. Cell 61: 1-3.

Ashburner, M. and H.D. Berendes. 1978. Puffing of polytene chromosomes. In The genetics and biology of Drosophila. (ed. M. Ashburner and T.R.F. Wright), Vol. 2B, pp. 453-498 Academic Press, New York.

Ashburner, M. and J.J. Bonner. 1979. The induction of gene activity in Drosophila by heat shock. Cell 17: 241-254.

Ashburner, M., C. Chihara, P. Meltzer, and G. Richards. 1974. Temporal control of puffing activity in polytene chromosomes. Cold Spring Harbor Symp. Quant. Biol. 38: 655-662.

Berg, J.M. 1988. Proposed structure for the zinc-binding domains from transcription factor IIIA and related proteins. Proc. Natl. Acad. Sci. 85: 99-102.

1990. Zinc fingers and other metal-binding domains. $J$.
Biol. Chem. 265: 6513-6516.

Brown, N.H. and F.C. Kafatos. 1988. Functional cDNA libraries from Drosophila embryos. J. Mol. Biol. 203: 425-437.

Burtis, K.C., C.S. Thummel, C.W. Jones, F.D. Karim, and D.S. Hogness. 1990. The Drosophila 74EF early puff contains E74, a complex ecdysone-inducible gene that encodes two etsrelated proteins. Cell 61: 85-99.

Caizergues-Ferrer, M., P. Moriottini, C. Curie, B. Lapeyre, N. Gas, F. Amalric, and F. Amaldi. 1989. Nucleolin from Xenopus laevis: cDNA cloning and expression during development. Genes \&) Dev. 13: 324-333.

Cavener, D.R. 1987. Comparison of the consensus sequence flanking translational start sites in Drosophila and vertebrates. Nucleic Acids Res. 15: 1353-1361.

Cleveland, D.W., S.G. Fischer, M.W. Kirschner, and U.K. Laemmli. 1977. Peptide mapping by limited proteolysis in sodium dodecyl sulfate and analysis by gel electrophoresis. I. Biol. Chem. 252: 1102-1106.

Cobianchi, F., D.N. SenGupta, B.A. Zmudzka, and S.H. Wilson. 1986. Structure of rodent helix-destabilizing protein revealed by cDNA cloning. I. Biol. Chem. 261: 3536-3543.

Dingwall, C. and R.A. Laskey. 1986. Protein import into the cell nucleus. Annu. Rev. Cell Biol. 2: 367-390.

Dingwall, C., S.M. Dilworth, S.J. Black, S.E. Kearsey, L.S. Cox, and R.A. Laskey. 1987. Nucleoplasmin cDNA sequence reveals polyglutamic acid tracts and a cluster of sequences homologous to putative nuclear localization signals. EMBO J. 6: 69-74.

Dreyfuss, G. 1986. Structure and function of nuclear and cytoplasmic ribonucleoproteins. Annu. Rev. Cell Biol. 2: 459498.

Earnshaw, W.C. 1987. Anionic regions in nuclear proteins. $/$. Cell Biol. 105: 1479-1482.

Elgin, S.C.R. and D.W. Miller. 1977. Mass rearing of flies and mass production and harvesting of embryos. In The genetics and biology of Drosophila /ed. M. Ashburner and T.R.F. Wright), Vol. 2A, pp. 112-121. Academic Press, New York.

Elgin, S.C.R., S.A. Amero, J.C. Eissenberg, G. Fleischmann, D.S. Gilmour, and T.C. James. 1988. Distribution patterns of nonhistone chromosomal proteins on polytene chromosomes: Functional correlations. In Chromosome structure and function (ed. J.P. Gustafson and R. Appels), pp. 145-156. Plenum, New York.

Feinberg, A.P. and B. Vogelstein. 1983. A technique for radiolabeling DNA restriction endonuclease fragments to high specific activity. Anal. Biochem. 132: 6-13.

Fisher, P.A., L, Lin, M. McConnell, A. Greenleaf, J.-M. Lee, and D.E. Smith. 1989. Heat shock-induced appearance of RNA polymerase II in karyoskeletal protein-enriched (nuclear "marix"| fractions correlates with transcriptional shutdown in Drosophila melanogaster. I. Biol. Chem. 264: 3464-3469.

Fleischmann, G., G. Pflugfelder, E.K. Steiner, K. Javaherian, G.C. Howard, J.C. Wang, and S.C.R. Elgin. 1984. Drosophila DNA topoisomerase $\mathrm{I}$ is associated with transcriptionally active regions of the genome. Proc. Natl. Acad. Sci. 81: 6958-6962.

Galfré, G. and C. Milstein. 1982. Preparation of monoclonal antibodies: Strategies and procedures. Methods Enzymol. 73: 3-46.

Garbe, J.D. and M.L. Pardue. 1986. Heat shock locus 93D of Drosophila melanogaster: A spliced RNA most strongly conserved in the intron sequence. Proc. Natl. Acad. Sci. 83: 1812-1816.

Harrison, S.D. and A.A. Travers. 1990. The tramtrak gene encodes a Drosophila finger protein that interacts with the $f t z$ transcriptional regulatory region and shows a novel embry- 
onic expression pattern. EMBO I. 9: 207-216.

Haynes, S.R., G. Raychaudhuri, and A.L. Beyer. 1990. The Drosophila Hrb98DE locus encodes four protein isoforms homologous to the $\mathrm{Al}$ protein of mammalian heterogeneous nuclear ribonucleoprotein complexes. Mol. Cell. Biol. 10: $316-323$.

Hodgetts, R.B., B. Sage, and J.D. O'Connor. 1977. Ecdysone titres during postembryonic development of Drosophila melanogaster. Dev. Biol. 60: 310-317.

Hultmark, D., R. Klemenz, and W.J. Gehring. 1986. Translational and transcriptional control elements in the untranslated leader of the heat-shock gene hsp22. Cell 44: 429-438.

Huynh, T.R., R.A. Young, and R.W. Davis. 1985. Constructing and screening cDNA libraries in $\lambda g t 10$ and $\lambda g t 11$. In DNA Cloning (ed. D.M. Glover), Vol. 1, pp. 49-78. IRL Press, Oxford.

James, T.C. and S.C.R. Elgin. 1986. Identification of a nonhistone chromosomal protein associated with heterochromatin in Drosophila melanogaster and its gene. Mol. Cell. Biol. 6: 3862-3872.

Johnson, P.F. and S.L. McKnight. 1989. Eukaryotic transcriptional regulatory proteins. Annu. Rev. Biochem. 58: 799839.

Joho, K.E., M.K. Darby, E.T. Crawford, and D.D. Brown. 1990. A finger protein structurally similar to TFIIIA that binds exclusively to 5S RNA in Xenopus. Cell 61: 293-300.

Kozak, M. 1989. The scanning model for translation: An update. J. Cell Biol. 108: 229-241.

Kraminsky, G.P., W.C. Clark, M.A. Estelle, R.D. Gietz, B.A. Sage, J.D. O'Connor, and R.B. Hodgetts. 1980. Induction of translatable mRNA for dopa decarboxylase in Drosophila: An early response to ecdysterone. Proc. Natl. Acad. Sci. 77: 4175-4179.

Laemmli, U.K. 1970. Cleavage of structural proteins during the assembly of the head of bacteriophage T4. Nature 227: 680685.

Lee, M.S., G.P. Gippert, K.V. Soman, D.A. Case, and P.E. Wright. 1989. Three-dimensional solution structure of a single zinc finger DNA-binding domain. Science 245: 635-637.

Lefevre, G. Jr. 1976. A photographic representation and interpretation of the polytene chromosomes of Drosophila melanogaster salivary glands. In The genetics and biology of Drosophila (ed. M. Ashburner and E. Novitski), Vol. la, pp. 31-66. Academic Press, New York.

Lewin, B. 1990. Commitment and activation of Pol II promoters: A tail of protein-protein interactions. Cell 61: 11611164.

Maniatis, T., E.F. Fritsch, and J. Sambrook, eds. 1982. Extraction, purification, and analysis of mRNA from eukaryotic cells. In Molecular cloning: A laboratory manual, pp. 187210. Cold Spring Harbor Laboratory, Cold Spring Harbor, New York.

Mayfield, J.E., L.A. Serunian, L.M. Silver, and S.C.R. Elgin. 1978. A protein released by DNAse I digestion of Drosophila nuclei is preferentially associated with puffs. Cell 14: 539544.

Miesfeld, R., S. Rusconi, P.F. Godowski, B.A. Maler, S. Okret, A.-C. Wikstrom, J.-A. Gustafsson, and K.R. Yamamoto. 1986. Genetic complementation of a glucocorticoid receptor deficiency by expression of cloned receptor cDNA. Cell 46: 389-399.

Miller, J., A.D. McLachlan, and A. Klug. 1985. Repetitive zincbinding domains in the protein transcription factor IIIA from Xenopus oocytes. EMBO I. 4: 1609-1614.

Moritz, T., J.E. Edstrom, and O. Pongs. 1984. Cloning of a gene localized and expressed at the ecdysteroid regulated puff
74EF in salivary glands of Drosophila larvae. EMBO J. 3: 289-295.

Mount, D.W. and B. Conrad. 1986. Improved programs for DNA and protein sequence analysis. Nucleic Acids Res. 14: 443454.

O'Connell, P. and M. Rosbash. 1984. Sequence, structure, and codon preference of the Drosophila ribosomal protein 49 gene. Nucleic Acids Res. 12: 5495-5513.

Pardue, M.L. 1986. In situ hybridization to DNA of chromosomes and nuclei. In Drosophila: A practical approach led. D.B. Roberts), pp. 111-138. IRL Press, Oxford.

Parker, C.S. and J. Topol. 1984. A Drosophila RNA polymerase II transcription factor contains a promoter region-specific DNA-binding activity. Cell 37: 273-283.

Pearson, W.R. and D.J. Lippman. 1988. Improved tools for biological sequence comparison. Proc. Natl. Acad. Sci. 85: 2444-2448.

Pongs, O. 1988. Ecdysteroid-regulated gene expression in Drosophila melanogaster. Eur. J. Biochem. 175: 199-204.

Proudfoot, N.J. and E. Whitelaw. 1988. Termination and 3 '-end processing of eukaryotic RNA. In Transcription and splicing, (ed. B.D. Hames, and D.M. Glover), pp. 97-129. IRL Press, Oxford.

Ptashne, M. 1988. How eukaryotic transcriptional activators work. Nature 335: 683-689.

Richards, G. 1981. The radioimmune assay of ecdysteroid titres in Drosophila melanogaster. Mol. Cell. Endocrinol. 21: 181197.

Ritossa, F.M. 1962. A new puffing pattern induced by temperature shock and DNP in Drosophila. Experientia 18: $571-$ 573.

Ryseck, R.-P., U. Walldorf, and B. Hovemann. 1985. Two major RNA products are transcribed from heat-shock locus 93D of Drosophila melanogaster. Chromosoma 93: 17-20.

Sass, H. 1982. RNA polymerase B in polytene chromosomes: Immunofluorescent and autoradiographic analysis during stimulated and repressed RNA synthesis. Cell 28: 269-278.

Sass, H. and T. Pederson. 1984. Transcription-dependent localization of $\mathrm{U} 1$ and $\mathrm{U} 2$ small nuclear ribonucleoproteins at major sites of gene activity in polytene chromosomes. J. Mol. Biol. 180: $911-926$.

Segraves, W.A. and D.S. Hogness. 1990. The E75 ecdysone-inducible gene responsible for the 75B early puff in Drosophila encodes two new members of the steroid receptor superfamily. Genes \&) Dev. 4: 204-210.

Silhavy, T.J., M.L. Berman, and L.W. Enquist. 1984. Preparation of 2-ml high-titer $\lambda$ liquid lysates. In Experiments with gene fusions, pp. 89-90, Cold Spring Harbor Laboratory, Cold Spring Harbor, New York.

Silver, L.M. and S.C.R. Elgin. 1977. Distribution patterns of three subfractions of Drosophila nonhistone chromosomal proteins: Possible correlations with gene activity. Cell 11: 971-983.

Spradling, A., M.L. Pardue, and S. Penman. 1977. Messenger RNA in heat-shocked Drosophila cells. I. Mol. Biol. 109: 559-587.

Staden, R. 1980. A new computer method for the storage and manipulation of DNA gel reading data. Nucleic Acids Res. 8: 3673-3694.

Struhl, K. 1989. Helix-turn-helix, zinc-finger, and leucine-zipper motifs for eukaryotic transcriptional regulatory proteins. Trends Biochem. Sci. 14: 137-140.

Sung, P., S. Prakash, and L. Prakash. 1988. The RAD6 protein of Saccharomyces cerevisiae polyubiquinates histones, and its acidic domain mediates this activity. Genes \& Dev. 2: 14761485 . 
Thummel, C.S., K.C. Burtis, and D.S. Hogness. 1990. Spatial and temporal patterns of E74 transcription during Drosophila development. Cell 61: 101-111.

Urness, L.D. and C.S. Thummel. 1990. Molecular interactions within the ecdysone regulatory heirarchy: DNA binding properties of the Drosophila ecdysone-inducible E74A protein. Cell 63: 47-61.

Weeks, J.R., D.E. Coulter, and A.L. Greenleaf. 1982. Immunological studies of RNA polyemrase II using antibodies to subunits of Drosophila and wheat germ enzyme. $/$. Biol. Chem. 257: 5884-5891.

Wingender, E. 1988. Compilation of transcription regulating proteins. Nucleic Acids Res. 16: 1879-1902.

$\mathrm{Wu}, \mathrm{C}$. 1984. Two protein-binding sites in chromatin implicated in the activation of heat-shock genes. Nature 309: 229-234.

Yost, H.J. and S. Lindquist. 1986. RNA splicing is interrupted by heat shock and is rescued by heat shock protein synthesis. Cell 45: 185-193.

Zieve, G.W. and R.A. Sauterer. 1990. Cell biology of the snRNP particles. Crit. Rev. Biochem. Mol. Biol. 25: 1-46.

Zimmerman, J.L., W. Petri, and M. Meselson. 1983. Accumulation of a specific subset of $D$. melanogaster heat shock $\mathrm{mR}$ NAs in normal development without heat shock. Cell 32: 1161-1170. 


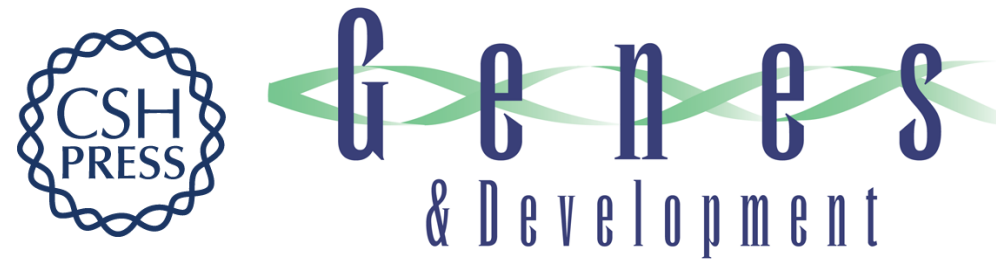

\section{A unique zinc finger protein is associated preferentially with active ecdysone-responsive loci in Drosophila.}

S A Amero, S C Elgin and A L Beyer

Genes Dev. 1991, 5:

Access the most recent version at doi:10.1101/gad.5.2.188

References This article cites 64 articles, 18 of which can be accessed free at:

http://genesdev.cshlp.org/content/5/2/188.full.html\#ref-list-1

License

Email Alerting

Service

Receive free email alerts when new articles cite this article - sign up in the box at the top right corner of the article or click here.

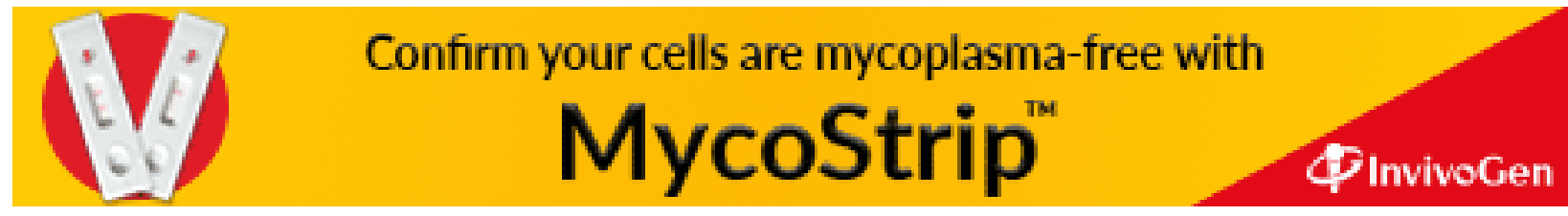

